\title{
Hydrogen-rich gas production from woody spent mushroom beds via two-step gasification
}

\author{
Yasuo Kojima ${ }^{*} \cdot$ Yoshiaki Kato $^{1} \cdot$ Seung-Lak Yoon ${ }^{2}$ \\ ${ }^{1}$ Department of Applied Biochemistry, Niigata University, Japan \\ ${ }^{2}$ Department of Interior Materials Engineering, Gyeongnam National University of Science and Technology, \\ Korea \\ * Corresponding author: Fax: 81-25-262-6854, and/or e-mail: koji@agr.niigata-u.ac.jp
}

\begin{abstract}
To evaluate spent mushroom beds (log and sawdust beds) as a two-step gasification resource, carbonization of spent mushroom beds for the production of char and gasification of the chars were performed using a small laboratory system. Carbonization of the mushroom beds at $600{ }^{\circ} \mathrm{C}$ produced suitable chars as the source for steam gasification. In addition, the wood gas produced during the carbonization process had a sufficient higher heating value and thus could be used as the fuel for the gasification step. The gasification of the spent bed chars produced clean hydrogen-rich gases without generation of any by-products. On the other hand, direct gasification of a waste $\log$ bed generated hydrocarbon and tar-like materials. Furthermore, the water-gas reaction $(\mathrm{C}+\mathrm{H} 2 \mathrm{O} \rightarrow \mathrm{CO}+\mathrm{H} 2)$ was proposed as the mechanism for the gasification process.
\end{abstract}

Key words: two-step gasification, carbonization, steam gasification, mushroom culture bed

\section{INTRODUCTION}

Countries in eastern Asia and Japan, such as many EU countries, have little or no reserves of good quality fossil fuels and thus must depend on imported energy. Therefore, it is in the national interest of these countries to develop alternative energy resources. The gasification of biomass (wood-based materials, agricultural residues, forestry waste, etc.) is a promising technology that provides a competitive means for producing chemicals and energy from renewable energy sources [1]. The gas mixture generated during the gasification process can be utilized in both conventional and advanced technologies for the production of electrical energy, thermal power and as transportation fuels. Such fuels derived from biomass are environmentally favorable because they are considered to be carbon neutral $[2,3]$. Syngas which has direct application in hydro-treating operations, ammonia production and the synthesis of methanol, dimethyl ether and super-clean liquid fuels (such as Fischer-Tropsch oil) can also be produced from gasification products $[2$, 4]. Furthermore, there is growing demand for hydrogen because of its increasing use as fuel. Currently, hydrogen gas is largely produced via the catalytic reforming of natural gas, liquefied petroleum gas and naphtha with steam. Such a process, however, results in a significant amount of carbon dioxide emissions and thereby contributes to global warming. For this reason, alternative methods for hydrogen production are being investigated, including direct gasification of biomass [5, 6]. A critical review of the relevant literature reveals that steam is the most widely accepted gasification agent for the production of hydrogen gas mainly because of the quality and high yield of the generated hydrogen [7]. Progress in hydrogen production from biomass has largely been hampered by technical issues associated with tar formation, which reduces the efficiency of gas production and interferes with equipment operation [8]. Formation of tar compounds generally renders the product gas mixture unsuitable for commercial applications. Therefore, numerous studies have been conducted on the elimination/destruction of tar compounds formed during biomass gasification [9-12]. Practical possibilities for tar removal/destruction other than in-bed and multi-step methods include highmedium temperature downstream methods that are typically based on catalytic tar cracking [13]. Processes such as hot electrostatic precipitation and adsorption by various solvents at temperatures below $400{ }^{\circ} \mathrm{C}$ are considered to be auxiliary methods [14].

Gasification generally consists of two primary steps: initial pyrolysis and subsequent char gasification. The latter is the rate-determining step that controls the overall conversion process [15]. Gasification of biomass chars has been investigated in order to gain a better understanding of char reactivity, and kinetic models have been reported using steam and carbon dioxide as gasification agents $[3,7,11-20]$. In addition, several studies have been reported on the gasification of biomass char from different types of biomass, e.g. grapefruit skins [21], Japanese cedar [22], sunflower shells [23], beech wood [24], slash pine [25] and bagasse [26]. Notably, Yan et al. attempted to produce hydrogen-rich gas via the steam gasification of char formed as a by-product in a fast pyrolysis liquefaction process [27]. They concluded that both high gasification temperature and introduction of the proper amount of steam led to a higher yield of dry gas and a higher carbon conversion efficiency. Umeki et al. also proposed that untreated char produced from high-temperature steam gasification systems can be extracted from the 
gasifier and combusted to generate high-temperature steam [3].

In Japan, some mushrooms are preferred as health foods; however, there is a limited supply of wild mushrooms, and they are very expensive. These mushrooms are therefore produced in culture beds, such as sawdust beds (SBs) and $\log$ beds. Approximately 430,000 t/year of mushroom bed are used in the mushroom industry in Japan, with 400,000 t/year as SB and 30,000 t/year as log beds, and the same quantity of spent mushroom beds is generated each year by mushroom farms after completion of the harvest. Most of the spent beds are left behind as residues called spent compost or post mushroom substrates and are not utilized. Finding good end applications for the spent mushroom beds is a worldwide industry concern. While composting of the spent mushroom beds has been reported [28], this practice is very limited. Pyrolytic conversion to fuel and chemicals is, therefore, an attractive alternative for recycling the spent mushroom beds. Spent mushroom substrates have been shown to be a good feedstock for gasification because they have high-energy content similar to that of fuel wood [29-31]. Williams et al. also reported that spent mushroom beds have potential as an energy feedstock with a high caloric value [32].

On the basis of the above information, we proposed a tar-free gasification system using spent mushroom bed chars as the gasification source. The system consists of two reactors: a carbonization furnace for char production and a gasifier. The wood gas and char produced in the carbonization reactor are separated, and the wood gas, including any tar, is directed to the outside of the gasification reactor, while the char is fed to the interior of the gasification reactor. The wood gas can be used as the heat source for the gasification unit in commercial plants. In the laboratory experiments, carbonization and gasification were separately performed, and a small electric furnace was used as the gasification reactor. To develop an effective and efficient process for the production of clean hydrogen gas from biomass char using steam, chars were prepared from various mushroom beds.

\section{EXPERIMENT}

2.1 Raw materials

Waste SBs formed from hardwood sawdust were provided by a mushroom grower, and waste log beds (Japanese oak, Quercus mongolica var. grosseseratta), unused $\operatorname{logs}$ (L0), logs used for 5 years (L5) and logs used for 5 years then left for 5 years (L10) were provided by the Forest Research Station at Hokkaido University. Photographs of these samples are shown in Fig. 1. The samples were dried and then cut to sizes ranging from 50 to $60 \mathrm{~mm}$ in length. Proximate analyses of the chars were performed according to JIS M8812. Elemental analysis was conducted using an elemental analyzer (J-Sciencelab Micro-corder JM10).

\subsection{Char preparation}

Preparation of the chars was performed by charging 400 $\mathrm{g}$ of mushroom bed pieces in a stainless-steel reactor with a length of $500 \mathrm{~mm}$ and an internal diameter of 80 $\mathrm{mm}$. The reactor was heated using a cylindrical electric furnace, and the temperature was monitored using $\mathrm{K}$-type thermocouples placed in the interior and on the exterior of the reactor. The reactor was heated for 180 min to $600{ }^{\circ} \mathrm{C}$ and then held at that temperature for 180 min. The chars produced from the L0, L5, L10 and SB samples are referred to as L0char, L5char, L10char and SBchar, respectively. In order to obtain more reliable data, each carbonization was repeated three times, and the average of the results was used. The char yields were calculated as follows:

Char yield $(\%)=100 \times$ dried char weight $(\mathrm{g}) / \mathrm{dried}$ mushroom bed weight $(\mathrm{g})$

The wood gases were then forced through a cyclone and collected in a gas bag behind a gas flow meter with which the produced gas volumes were recorded. The major gases, including $\mathrm{H} 2, \mathrm{CO}, \mathrm{CH} 4$ and $\mathrm{CO} 2$, were analyzed on a gas chromatograph (J-Sciencelab GC-7000T) equipped with a packed column $(2 \mathrm{~m} \times 3.2$ $\mathrm{mm}$ activated carbon) and a thermal conductivity detector (TCD) using argon as the carrier gas. The column oven temperature was $70{ }^{\circ} \mathrm{C}$ and the TCD current was $90 \mathrm{~mA}$. The higher heating values (HHVs) of the wood gases were calculated by using the HHV of each gas (H2: $12.75 \mathrm{MJ} / \mathrm{Nm} 3$; $\mathrm{CO}: 12.63 \mathrm{MJ} / \mathrm{Nm} 3$; CH4: $39.72 \mathrm{MJ} / \mathrm{Nm} 3)$.

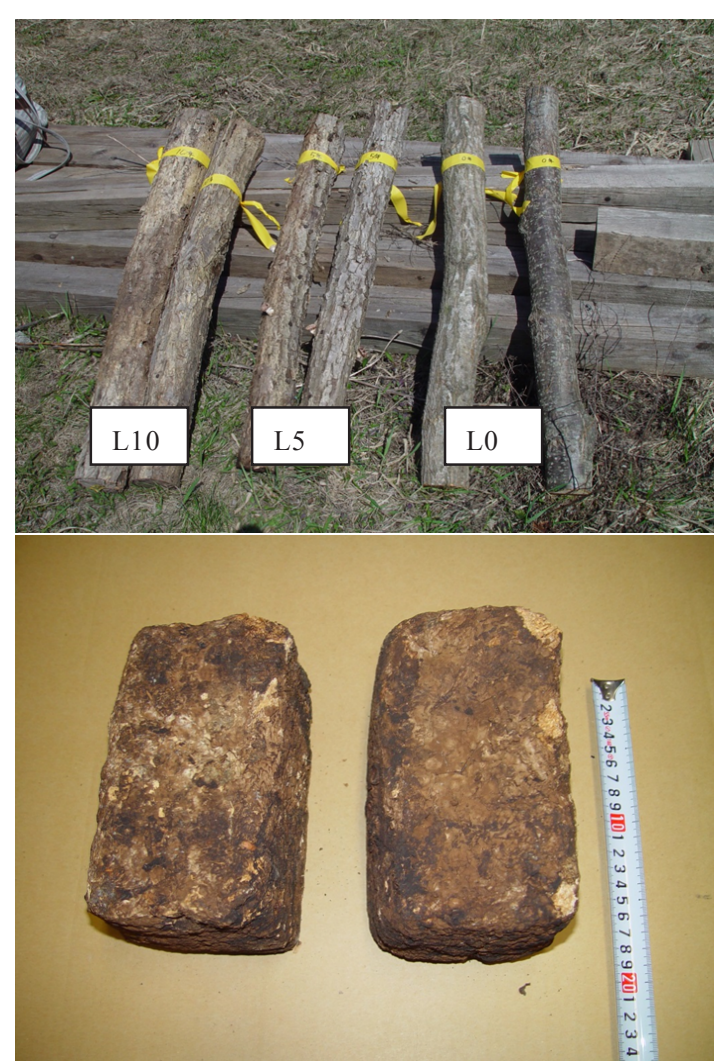

Fig.1 Photographs of waste log beds and sawdust beds

\subsection{Gasification}

The prepared mushroom bed chars were crushed and screened to obtain particle sizes from 5 to $10 \mathrm{~mm}$. A fixed bed gasifier was placed inside the electric furnace, and the char $(50 \mathrm{~g})$ was placed into the gasifier (Fig. 2). Prior to gasification, the air in the gasifier was forced through a cyclone and then replaced with nitrogen. The gasifier reached the desired temperature in $30 \mathrm{~min}$ after 
heating was initiated, and then steam was supplied to the gasifier using a water pump. Gasification of the mushroom bed chars was performed at $900{ }^{\circ} \mathrm{C}$ using a steam supply rate of $0.05 \mathrm{~g} / \mathrm{min} / \mathrm{g}$ char. For comparison, L10 was gasified directly. The generated gases were passed through a cyclone and a gasholder, and a gas meter was located behind the cyclone. The water gases were collected from the gasholder for measurement of the water gas composition, and the gas analysis was performed as described above for the carbonization step.

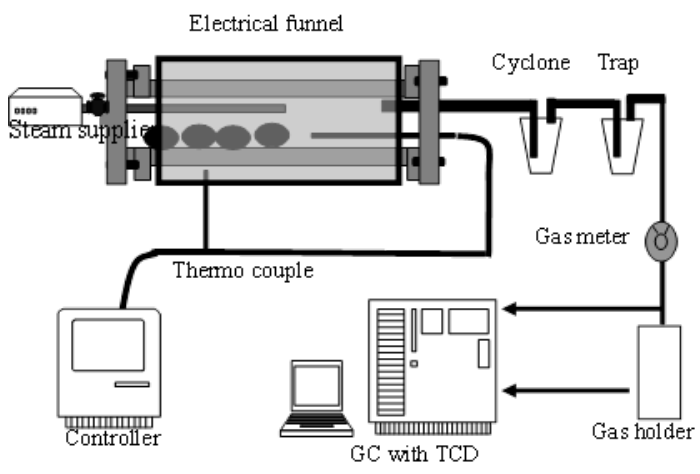

Fig.2 An illustration of gasifier used in this study

\section{RESULTS AND DISCUSSION}

3.1 Properties of the spent mushroom beds

The results for the proximate and ultimate analyses of the produced mushroom bed chars are shown in Table 1 .

Table 1 Proximate and ultimate analysis of spent mushroom bed

\begin{tabular}{|l|r|r|r|r|}
\hline Mushroom bed & \multicolumn{1}{|c|}{ L0 } & \multicolumn{1}{c|}{ L5 } & \multicolumn{1}{c|}{ L10 } & \multicolumn{1}{c|}{ SB } \\
\hline Moisture contents, \% & 11.2 & 10.7 & 11.9 & 9.7 \\
\hline Apparent density, kg/m3 & 0.788 & 0.392 & 0.344 & 0.267 \\
\hline Volatile matter, Wt. \% & 73.07 & 73.85 & 73.62 & 65.62 \\
\hline fixed carbon, Wt. \% & 11.52 & 10.13 & 9.61 & 12.37 \\
\hline Ash, Wt. \% & 4.21 & 4.82 & 4.89 & 12.11 \\
\hline C & 47.39 & 48.66 & 49.19 & 40.41 \\
\hline H & 5.47 & 5.62 & 5.74 & 5.21 \\
\hline N & 0.63 & 1.12 & 1.21 & 1.26 \\
\hline
\end{tabular}

The apparent density drastically decreased for the spent bed (L5) compared to L0. This result indicates that a portion of the carbohydrates in the log was decomposed and digested by the growing mushroom hyphae. Therefore, the $\mathrm{C}$ content of L5 was higher than that of L0 because of the loss of carbohydrates (C content for milled wood lignin: $58.4 \%$; for carbohydrate as cellulose: $40.0 \%$ [33]). In addition, the value for L10 was slightly higher than that of L5. On the other hand, the fixed carbon of L5 and L10 were lower than that of L0. It is hypothesized that biodegradation of the bed continued during ageing because of the presence of remaining mushroom hyphae and/or other microorganisms in the L10 sample. There was, however, no difference in the $\mathrm{H}$ content of the various mushroom $\log$ beds before and after cultivation. The SB, which is an artificially formed structure, has low $\mathrm{C}$ content and high ash content because of the presence of additives such as wheat bran and minerals that were used as nutrients during mushroom cultivation. The physical property data obtained for the SB were typical values [32]. A high $\mathrm{N}$ content in the spent mushroom beds was caused by the presence of remaining mushroom hyphae and/or other microorganisms, as mentioned above.

\subsection{Carbonization of the waste mushroom beds}

The results for the carbonization of the spent mushroom beds are listed in Table 2. No significant difference in the char yields was observed for the new (L0) and spent (L5 and L10) log beds, while the char yield for the SB was higher than that of the log beds because of the high ash content. The gas from char production is referred to as wood gas and can be used as fuel. Therefore, the gas yield and specific HHV of the wood gas are important factors. The yield of the gas produced during the carbonization of the spent mushroom beds slightly increased after mushroom cultivation (L5) and subsequent ageing (L10). The highest wood gas yield was obtained for SB carbonization. It is believed that inorganic compounds present in the ash in the samples act as gasification catalysts; the highest ash content was found in the SB, thus leading to a higher gas yield. On the contrary, the HHV of the wood gas from the beds decreased as a result of mushroom cultivation and ageing, and the lowest HHV wood gas was obtained from the SB.

Table 2 Preparation of chars from spent mushroom bed

\begin{tabular}{|l|r|r|r|r|}
\hline Mushroom bed & \multicolumn{1}{c|}{ L0 } & \multicolumn{1}{c|}{ L5 } & \multicolumn{1}{c|}{ L10 } & \multicolumn{1}{c|}{ SB } \\
\hline Char yield (wt. \%) & 33.38 & 32.68 & 31.1 & 40.36 \\
\hline $\begin{array}{c}\text { Wood gas product } \\
\left(\mathrm{m}^{3} / \mathrm{kg}\right)\end{array}$ & 0.26 & 0.27 & 0.28 & 0.39 \\
\hline $\mathrm{HHV}\left(\mathrm{MJ} / \mathrm{m}^{3}\right)$ & 12.51 & 12.48 & 12.02 & 11.48 \\
\hline Gas composition (Vol. \%) \\
$\mathrm{H}_{2}$ & 9.77 & 9.71 & 9.39 & 26.33 \\
$\mathrm{CO}$ & 29.33 & 27.49 & 25.14 & 14.92 \\
$\mathrm{CH}_{4}$ & 14.18 & 14.59 & 14.86 & 12.74 \\
$\mathrm{CO}_{2}$ & 46.73 & 48.26 & 50.61 & 46.02 \\
${ }^{*} \mathrm{HHV}=$ higher heating & value calculated by gas \\
composition & & \multicolumn{5}{l}{}
\end{tabular}

The HHV depends on the wood gas composition; CH4 has a higher caloric value than $\mathrm{H} 2$ and $\mathrm{CO}$. While there was no difference in the $\mathrm{H} 2$ content found in the wood gas from the log beds, the $\mathrm{CH} 4$ and $\mathrm{CO} 2$ content in the gases slightly increased; the $\mathrm{CO}$ content decreased after cultivation and ageing of the log beds. The decrease in $\mathrm{CO}$ content therefore significantly affected the HHV of the wood gases from these samples. Notably, the wood gas composition produced during SB carbonization differed from $\log$ beds; the $\mathrm{H}_{2}$ content of the wood gas from the SB was approximately three times greater than that from the log beds, while the CO content was about two times lower. As a result, the HHV of the wood gas from the SB was lower than that from the log beds [34]. 3.3 Gasification of the mushroom bed char

During gasification of the char with steam, clean fuel gases with high caloric values were produced. The final gas composition and HHV are the result of a series of complex and competing reactions shown below:

1) Water-gas reaction:

$$
\mathrm{C}+\mathrm{H}_{2} \mathrm{O} \rightarrow \mathrm{CO}+\mathrm{H}_{2}
$$

2) Boudouard reaction:

$$
\mathrm{C}+\mathrm{CO}_{2} \rightarrow 2 \mathrm{CO}
$$


3) Water-gas shift reaction:

$$
\mathrm{CO}+\mathrm{H}_{2} \mathrm{O} \rightarrow \mathrm{CO}_{2}+\mathrm{H}_{2}
$$

The water-gas reaction is a solid-gas heterogeneous reaction; thus, the reaction mechanism should be more complex. The proposed formation mechanism for $\mathrm{H}$ and $\mathrm{CO}$ from char with steam via the water-gas reaction is $5 \mathrm{C}+5 \mathrm{H}_{2} \mathrm{O} \rightarrow 5 \mathrm{CO}+5 \mathrm{H}_{2}$ (not including the initial release of $4 \mathrm{H}$ radicals from the char), as illustrated in Fig. 3. Char is a polycyclic polymer consisting of aromatic hydrocarbons [35], and the chemical structure shown in Fig. 3 has been used as a structural model of the char surface. In the first step of gasification, $\mathrm{H}$ radicals are released from the surface of the bio-char, and the remaining surface carbon radicals act as $\mathrm{OH}$ radical acceptors, resulting in the formation of $-\mathrm{C}-\mathrm{O}-\mathrm{H}$ structures at the char surface. A second release of $\mathrm{H}$ radicals from the $-\mathrm{C}-\mathrm{O}-\mathrm{H}$ groups leads to the generation of carbonyl compounds. Electron transfer then occurs at the adjacent $\mathrm{C}-\mathrm{C}$ bonds, and $\mathrm{CO}$ is formed. The chain reaction then continues on the char surface in the presence of $\mathrm{H}_{2} \mathrm{O}$.

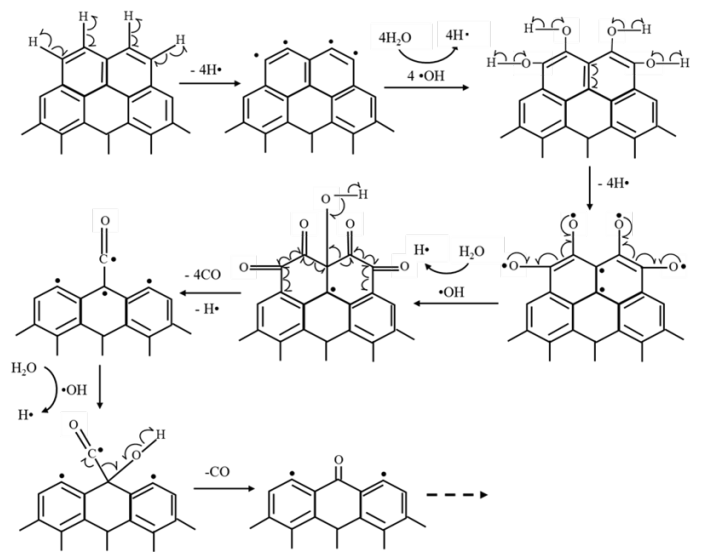

Fig.3 Proposed reaction mechanism of char with $\mathrm{H}_{2} \mathrm{O}$

Table 3 gasification of chars from spent mushroom bed

\begin{tabular}{|l|r|r|r|r|}
\hline Mushroom bed & L0 char & L5 char & L10 char & SB char \\
\hline $\begin{array}{l}\text { Water gas product } \\
\left(\mathrm{m}^{3} / \mathrm{kg} \text { of char }\right)\end{array}$ & 5.14 & 4.83 & 4.69 & 4.11 \\
\hline $\mathrm{HHV}\left(\mathrm{MJ} / \mathrm{m}^{3}\right)$ & 11.49 & 11.56 & 11.78 & 11.75 \\
\hline \multicolumn{4}{|c|}{ Gas composition, Vol. \% } \\
$\mathrm{H}_{2}$ & 61.53 & 61.12 & 61.46 & 59.66 \\
$\mathrm{CO}$ & 19.28 & 19.09 & 19.71 & 19.67 \\
$\mathrm{CH}_{4}$ & 0.56 & 1.07 & 1.06 & 1.55 \\
$\mathrm{CO}_{2}$ & 18.63 & 18.72 & 17.77 & 19.11 \\
\hline
\end{tabular}

The results for the steam gasification of the mushroom bed chars are listed in Table 3. Water gas production via steam gasification of the mushroom bed chars proceeded successfully, and results comparable to those obtained for wood char gasification were obtained. The gas yields from the cultivated and aged log chars were lower than that for L0, and the lowest gas yield was obtained for the SB char because of the high ash content in the char. However, a high gas production efficiency was achieved (over $4 \mathrm{~m} 3 / \mathrm{kg}$ of char) using all of the chars from the mushroom beds. The HHV of the char was similar to that of L10. During the gasification of each spent mushroom bed char, water gas with high hydrogen content (over 60 vol. \%) was produced. In addition, no major differences in the compositions of the water gases were observed for the various spent mushroom beds used in this study. The molar ratio of $\mathrm{H} 2 / \mathrm{CO}$ was $3.2,3.5,3.1$ and 3.0 for $\mathrm{L} 0, \mathrm{~L} 5, \mathrm{~L} 10$ and SB, respectively. This result indicates that the gasification reaction in each of the spent mushroom beds occurred to the same degree. Generation of by-products, such as tar, was not observed in the gasification process, and clean water gases were obtained. Therefore, the gases produced via steam gasification of the spent mushroom bed chars did not require any cleaning or reforming after gasification. The yields of the gasification products were calculated on the basis of the dry bed weight and are shown in Fig. 4. The L0 and SB chars yielded approximately $1 \mathrm{~m} 3 \mathrm{H} 2 / \mathrm{kg}$ of dry bed, while the L5 and L10 chars produced over $0.9 \mathrm{~m} 3 \mathrm{H} 2 / \mathrm{kg}$ of dry bed.

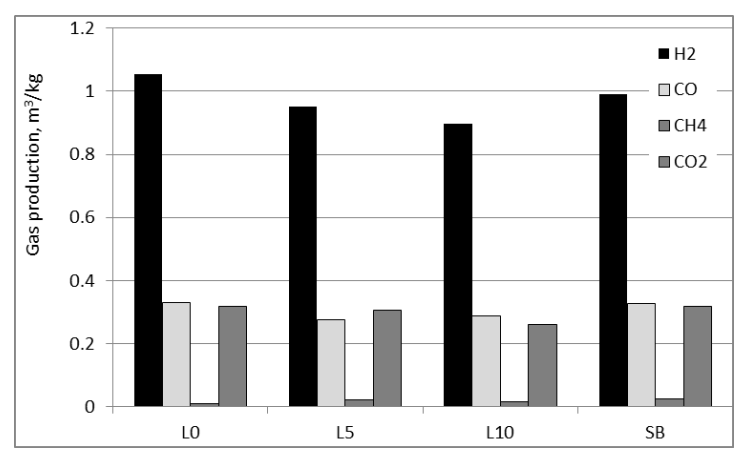

Fig. 4 Yield of gasification products

3.4 Comparison of one- and two-step gasification reactions

To evaluate the advantages of two-step gasification (carbonization and gasification), direct steam gasification was performed using L10. The results for the one- and two-step gasification of this sample are compared in Table 4. The HHV of the water gas from direct gasification of L10 was higher than that from the L10 char because of the higher content of $\mathrm{CO}$ and $\mathrm{CH} 4$. However, a significant amount of tar formation was also observed, and tar contaminated the water gas produced from direct gasification of the L10 sample. Thus, it would not be possible to use the water gas produced from direct gasification without cleaning and reforming. In addition, according to the gas production values in Table 4 (calculated on the basis of the dry L10 bed weight), the gas yield from the L10 char is apparently lower than that from L10. However, it should be noted that, during carbonization of L10 to produce the L10 char, volatile matter was released as wood gas and tar that can be used as heating fuel for the gasification step. In the case of L10, a greater amount of fuel must be purchased as the heating fuel for the gasification process that is required for the carbonization process.

A comparison of the gas compositions produced during the one- and two-step gasification processes is illustrated in Fig. 5. Interestingly, approximately $0.8 \mathrm{~m} 3$ $\mathrm{H} 2 / \mathrm{kg}$ of dry bed was produced via direct gasification of L10. While this value is slightly lower than the $\mathrm{H} 2$ yield obtained from steam gasification of the L10 char, this result suggests that a fairly large volume of hydrogen 
gas can be obtained via the direct steam gasification of spent mushroom log beds. In addition, the $\mathrm{CO}$ and $\mathrm{CO} 2$ yields for the direct gasification of L10 were higher than those for the gasification of the L10 char, and the CH4 content in the water gas produced via direct gasification was higher because hydrocarbons, such as $\mathrm{CH} 4$, were directly generated from the lignin and carbohydrates in the mushroom beds as well as from tar.

Table 4 Comparison of gasification results of LB10 and LB10 char

\begin{tabular}{|l|r|r|}
\hline & L10 Char & \multicolumn{1}{c|}{ L10 } \\
\hline HHV $\left(\mathrm{MJ} / \mathrm{m}^{3}\right)$ & 11.77 & 12.58 \\
\hline Gas production & 1.461 & 1.557 \\
$\left(\mathrm{~m}^{3} / \mathrm{kg}\right.$ of dry bed $)$ & $0.898(61.4)$ & $0.816(52.4)$ \\
$\mathrm{H}_{2}$ & $0.288(19.7)$ & $0.356(22.9)$ \\
$\mathrm{CO}$ & $0.015(1.1)$ & $0.067(4.3)$ \\
$\mathrm{CH}_{4}$ & $0.259(17.8)$ & $0.318(20.4)$ \\
$\mathrm{CO}_{2}$ & *Values in the parenthesis mean vol. \% in water gas
\end{tabular}

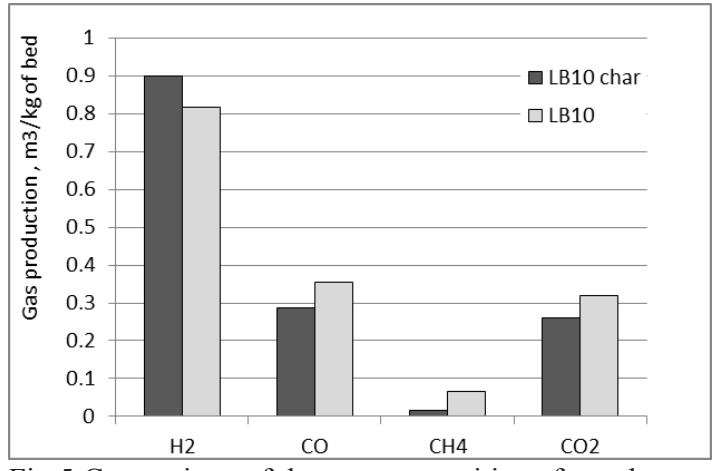

Fig.5 Comparison of the gas compositions form the onestep process with two-step processes

\section{CONCLUSION}

Spent mushroom beds (log and SB) were evaluated as a two-step gasification resource, and carbonization of spent mushroom beds for the production of char and gasification of the chars were performed using a small laboratory apparatus. Carbonization of the mushroom beds at $600{ }^{\circ} \mathrm{C}$ produced chars that were suitable raw materials for steam gasification. The wood gas produced during the carbonization process could be used as heating fuel for the gasification step because it had a sufficient HHV. Gasification of the spent bed chars produced clean, hydrogen-rich gases without generation of any by-products. On the other hand, direct gasification of waste $\log$ beds generated hydrocarbons and tar-like materials. In addition, the water-gas reaction $(\mathrm{C}+\mathrm{H} 2 \mathrm{O} \rightarrow \mathrm{CO}+\mathrm{H} 2)$ was proposed as the mechanism for the gasification process.

\section{REFERENCES}

[1] A.V. Bridgwater, Chem. Eng. J. 91, 87-102 (2003). [2] E. Cetin, B. Gupta, B. Moghtaderi, Fuel, 84, 1328-1334 (2005).

[3] K. Umeki, T. Namioka, K. Yosikawa, Fuel Processing Technology, 94, 53-64 (2012).

[4] K. Kim, Y. Kim, C. Yang, J. Moon, B. Kim, J. Lee, U. Lee, S. Lee, J. Kim, W. Eom, S. Lee, M. Kang, Y. Lee, Bioresource Technology, 127, 391-399 (2013).
[5] L. Wang, C.L. Weller, D.D. Jones, M.A. Hanna, Biomass Bioenergy, 32, 573-581 (2008).

[6] K. Kawamoto, W. Wu, H. Kuromachi. J. Environ. Eng. , 4, 409-421 (2009).

[7] F. Mermoud, S. Salvador, L. Van de Steene, F. Golfier Fuel, 85, 1473-1482 (2006).

[8] Q. Sun, S. Yu, F. Wang J. Wang, Fuel, 90, 1041-1048 (2011).

[9] J. Rath, G. Staudinger, Fuel, 80, 1379-1389 (2001).

[10] L. Devil, K.J. Ptansinski, F. Jansen, Biomass Bioenergy, 24, 125-140 (2003).

[11] X.T. Li, J.R. Grace, C.J. Lim, A.P. Watkinson, H.P. Chen, JR. Kim, Biomass Bioenergy, 26, 171-193 (2004). [12] J. Han, H. Kim, Renew. Sust. Energy Rev., 12, 397-416 (2008).

[13] J. Sulk, J. Stojdl, M. Richter, J. Popelka, K. Svoboda, J. Smetana, J. Vacek, S. Skoblja, P. Buryan, Waste Management, 32, 692-700 (2012).

[14] R.W.R. Zwart, Report ECN Petten, ECN-08-078, Netherland, (2009).

[15] Y. Zhang, M. Ashizawa, S. Kajitani, K. Miura, Fuel, 87, 475-481 (2008).

[16] E. Cetin, B. Moghtaderi, B. Gupta, T.F. Wall, Fuel, 83, 2139-2150 (2004).

[17] W. Klose, M. Wolki, Fuel, 84, 885-892 (2005).

[18] D.G. Roberts, D.J. Harris, Fuel, 86, 2672-2678 (2007).

[19] S. Nilsson, A. Gomez-Barea, D.F. Cano, Fuel, 92, 346-353 (2012).

[20] G. Teixeira, L. Van den Steen, E. Martin, F. Gelix, S. Salvador, Fuel, 102, 514-524 (2012).

[21] F.M. Montesions, T. Cordero, J.J. Mirasol, Fuel, 81, 423-429 (2002).

[22] K. Matsumoto, K. Takeno, T. Ichinose, T. Ogi, M. Nakanishi, Fuel, 88, 519-527 (2009).

[23] H. Haykiri-Acma, S. Yaman, S. Kucukbayrac, Energy Convers. Manage., 47, 1004-1013 (2006).

[24] K. Wolfgang, W. Michael, Fuel, 84, 885-892 (2005).

[25] J. Fermoso, C. Stevanov, B. Moghtaderi, B. Arias, C. Pevida, M.G. Plaza, F. Rubiera, J.J. Pis, J. Anal. Appl. Pyrolysis, 85, 287-293 (2009).

[26] S.T. Chaudhari, A.K. Dalai, N.N. Bakhshi, Energy Fuels, 17, 1062-1067 (2003).

[27] F. Yan, S.Y. Lio, Z.Q. Hu, B. Xiao, G. Cheng, Bioresouces Technology, 101, 5633-5637 (2010).

[28] D.L. Rinker, UAEM. Sanchez et al (eds), ISBN 968-878-105-3 (2002).

[29] N. Tippayawong, C. Chaichana, A. Promwungkwa, P. Rerkkriangkrai, International Journal of Energy, 4, 96-103 (2011).

[30] B.C. Williams, J.T. McMullan, S. McCahey, Bioresource Technology, 79, 227-230 (2001).

[31] K.N. Finney, C. Ryu, V.N. Sharifi, J. Swithenbank, Bioresource Technology, 100, 310-315 (2009).

[32] B.C. Williams, J.T. McMullan, S. McCahey, Bioresource Technology, 79, 227-230 (2001).

[33] A. Sato, T. Kitamura, T. Higuchi, Wood research (bulletin of the Wood Research Institute Kyoto University), 59/60, 93-100 (1976).

[34] B. Moghtadei, Fuel, 86, 2422-2430 (2007).

[35] J.K. Brennan, T.J. Bandosz, K.T. Thomson, K.E. Gubbins, Colloids and Surfaces A: Physicochemical and Engineering Aspects, 187/188, 539-568(2001).

(Received October 21, 2014; Accepted December 3, 2014) 